\title{
Analysis of options for Maximizing Local Government internally generated Revenue in Nigeria
}

\author{
Moses Atakpa, Ph.D. \\ Head of Service, Kogi State, Nigeria \\ Stephen Ocheni, Ph.D. \\ Ministry of Foreign Affairs, Abuja \\ Email: stephenocheni@yahoo.com
}

Basil C. Nwankwo, Ph.D.

Professor and Dean, Faculty of Management Sciences, Kogi State University, Anyigba, Nigeria

Email: basil.nwankwoy2k@yahoo.com

Accepted: August 10, 2012 Published: September 05, 2012

Doi:10.5296/ijld.v2i5.2345 URL: http://dx.doi.org/10.5296/ijld.v2i5.2345

\begin{abstract}
This study examined the various options for maximizing internal revenue generation in the Nigerian local governments. It took critical and hard look on the various sources of internal revenue in the local governments, problems of exploiting the various sources for revenue generation, and the reason why most of the sources remain untapped or under-tapped by the local government in Nigeria. The study suggested feasible and pragmatic ways to maximize internal revenue generation in the local governments. It observed that prior to 1976 Local Government Reform; most local governments were able to maximize their internal revenue generation and discharged their primary responsibilities with little or no financial assistance from the higher tier governments. However, with the introduction of statutory allocations to the local governments following the 1976 Reform, most of the local governments abandoned the hitherto viable internal revenue sources in preference to the revenue from statutory allocation. This unwholesome attitude of most local governments, among others, was identified as the bane of internal revenue generation at this level of government. The paper concludes, by stating that unless the local governments look inwards to maximize their internal revenue sources it cannot be financially self-reliant. The implication of this is that it cannot enjoy reasonable degree of autonomy as a third tier of government if it continues to be heavily dependent on the financial assistance from both the federal and the state governments, to be able to function effectively. The reason is because as the saying goes, "he who pays the piper dictates the tune."
\end{abstract}


Keywords: Local Government, Revenue, Reforms, and Administration

\section{Introduction}

The 1976 Local Government Reforms in Nigeria has since remained the greatest in the development of local government administration in the country. The aims and objectives of the Reform were meant to make the local government in Nigeria a real third tier or level of governmental administration after the Federal and State Governments.

The main thrust of the reform was to enable the local government extend social services and the development of rural infrastructure to the grassroots. It was in recognition of these objectives that the Fourth Schedule of 1979 Constitution of the Federal Republic of Nigeria, outlined in detail, the development functions of local governments in Nigeria.

In addition to the participation by the local governments with state government in drawing up the economic development policies and programs of the state, local governments should also provide, maintain and control social services at the local government level. Local governments also have responsibility for primary education, agriculture and natural resources, primary health services, construction and maintenance of rural roads and rural market.

Also, the Committee on the Review of Local Government Administration in Nigeria, 1984 (otherwise referred to as the Dasuki Committee) recommended the following basic/detailed functions which should be carried out through strict compliance with the budgetary guidelines to be set annually by the Local Government Council in their Approved Annual Estimates:

a) Basic environmental sanitation and other aspects of preventive health;

b) Provision of maternity centers, dispensaries, leprosy clinics and health centre;

c) Construction and maintenance of roads, drains, excluding Federal and State roads;

d) Local inland waterways not designated for international waterways;

e) Provision of rural water supply and extension of urban supply;

f) Community Development;

g) Agriculture and Veterinary Extension Services;

h) Construction, maintenance and equipment of primary schools;

i) Town and country planning;

j) Markets, motor parks, parks and gardens;

k) Maintenance of law and order; and

1) Afforestation.

In order to be able to carry out these functions at the grassroots, the Federal Military Government extended in 1976, a grant of $\$ 100$ million to the then 301 Local Government Areas in the country and also proceeded, in 1977, to appoint the Aboyade Technical Committee on Revenue Allocation to determine a revenue formula that would entrench into the 1979 Constitution of the Federal Republic of Nigeria. Even though the recommendations of this committee were not included in the 1979 Constitution, the Revenue Act of 1981, in accordance with Section 149 of the 1979 Constitution, made local governments in Nigeria, for the first time, to be recognized and included among the three tiers of government that would benefit from the statutory allocation of the Federation Account; and the following formula was adopted for the local governments:

$>10$ percent share of the Federation Account; 
$>10$ percent share from the total revenue of the state;

$>$ Internally generated revenues of the local government from community taxes and rents, fees, charges, licenses, moneys accruing from commercial ventures embarked upon by the individual local governments, rents on local government landed properties, interest payments, premiums and dividends from shares and other investments on private or public companies, loans and legal gift from private individuals and corporate bodies, etc.

Since then, many modifications have been made to the above formula all seeking to enhance the local governments' revenue generating capacity especially from the Federation Account. The share going to the local governments in Nigeria from the Federation Account has been fixed at 20 percent.

However, prior to the Revenue Act of 1981 and the availing of the Federation Account as a result of bulging oil proceeds of the 1980s, most local governments in the country had a greater share of their total revenue coming from internally generated revenue. (The percentage of internal revenue generated to the total revenue was as high as 85 for some local governments, between 1962 and 1983).

However, with the oil book of the 1980s and a one-time Head of State of Nigeria claiming that not finance, but executive capacity, was the major bottleneck to Nigeria's economic growth and development, some political parties, capitalizing on this rather regrettable statement, abolished some local taxes in the state they controlled. The result was that starting from 1976, statutory allocations from the Federation Account came to play highly increasing role in the total of ratio of total revenue generated by local governments in Nigeria. However, even the oil book and revenue accruing to the Federation Account started declining as from 1983. With this dwindling of revenue sources to the local governments in Nigeria, it means that local governments in the country should seek for more potential/substantial areas of internal revenue generation if they are to execute their numerous responsibilities and programs to their people.

\section{Traditional Sources of Revenue to Local Governments in Nigeria}

As already mentioned above, internally generated revenue formed a greater bulk of the total revenues accruing to the local governments before 1976. With the 1976 Local Government Reforms, these sources were further widened to enable the local governments to collect enough funds to discharge their development responsibilities. Consequently, the various local government edicts of the various states in the federation included the following as their major sources of revenue to all the local governments in the country:

a) Community Tax/Community Rates;

b) Property (Tenement) Rates;

c) General/Development/Capitation Rates;

d) Licenses, Fees and Charges

1) Advertisement fees

2) Baker houses licenses

3) Beggar minstrel fees

4) Bicycle licenses/hire permits

5) Births and deaths registration fees

6) Brick making and block industry licenses 
7) Cigarette sales licenses

8) Burial fees and charges (on local government burial grounds)

9) Cart/truck licenses

10) Cattle dealers/Butchers' licenses

11) Contractors' registration fees

12) Dane guns' control licenses

13) Dried fish and dried meat licenses

14) Dog licenses

15) Fishing/hunting fees

16) Forestry and fuel/fire wood exploitation fees

17) Goldsmith's licenses

18) Hawkers' permits/licenses

19) Hunting licenses

20) Local liquor brewing/sales licenses

21) Marriage registration fees

22) Minor/small/cottage industries licenses

23) Control of noise licenses

24) Palm wine fees

25) Pit sawing licenses

26) Produce (palm oil/kernel) buying/sales licenses

27) Rents and plot fees (from Landlords)

28) Retail trade licenses

29) Slaughter fees

e) Interest on Revenues

1) Interest on state deposits

2) Interests on investments

3) Profits from sale of investments/stocks, shares, etc.

f) Departmental Recurrent Revenues

1) Survey fees - from the Department of Works \& Planning

2) Repayment of personal advances

3) Refund of salaries and/or allowances

4) Refund of subsistence of students in training

5) Re-imbursement of state witnesses expenses

6) Sales of library books and literature

7) Nursery school and day-care centres fees

8) Conservancy or compost charge

9) Sale of produce e.g. palm oil/kernel

10) Profit on local government farm accounts

11) Tractor/grader/caterpillar hire fees

12) Irrigation fees

13) Sale of firewood

14) Sale of timber

15) Sale of produce

16) Cattle/goat/sheep/poultry treatment charges

17) Fodder

18) Stray animal poundage fees

19) Workshop repairs receipts

20) Sale on stores

21) Sale of unserviceable stores/vehicles, and equipment fees 
22) Rents on local government quarters

23) Guest/rent house fees/charges

24) Vehicles, plant and equipment charges

25) Profit vehicles advances account

26) Canoe/ferry/mass transit fees

27) Contribution for maintenance of produce evaluation road usage fees

28) Fees and charges in local government-maintained markets

29) Fees and charges in local government motor parks

30) Registration of business premises

31) Sale of corn

32) Sale of scrap metal, etc.

From the list, it is clear that many of the various sources of internally generated revenues to local governments are either untapped or under-tapped in most local governments in Nigeria. Some, like death registration fees, due to the culture and customs of local people can never be tapped; while others like tenement rates by individual and corporate persons can be potentially lucrative sources of local government revenue, if properly administered and strictly enforced. With courage, honesty, and fair-play local governments may not even bother to look for new sources of internal revenue if the above list is appropriately and adequately tapped and properly accounted for.

\section{Problems of Internal Revenue Generation and Collection in Nigerian Local Governments}

It is an indisputable and incontrovertible fact that the internal revenue generation of most local governments in Nigeria are far below what it should be, all things being equal. Several reasons have been adduced/advanced for why internal revenue generation is unsatisfactory. For example, the report of the committee on the federation in 1978/79 year observed that generally... the performance of local governments in revenue collection is very low. The following factors are responsible for the situation: poor communication network, particularly in the riverine areas of the country; lack of commitment on the part of some revenue collectors, some of whom are down-right dishonest; and defective revenue collecting machinery. In addition, some of the laws for revenue collection have not been updated by various state governments especially in areas of rating and tenement rates. In this regard, particular mention has been made of the local government areas in Kano and Kaduna states between 1979 and 1983.

Similarly, Adewumi (1994) observed that the major problems of internal revenue generation in the local government centre on... the inability of local governments to enforce by-laws which could enhance their revenue collection... For example, there are local governments that have approved laws on tenement rates which could relieve them of their dependence on the monthly allocation from Federation Account, but many of them have adopted nonchalant attitude towards this revenue source.

Similarly, local governments have been known to exhibit their inability to keep proper and adequate accounting records. In particular, many Chairmen and Councilors have little or no knowledge of the accounting systems in local governments. To them, that should be left to the experts who are in short supply in local government. All these have combined with the relaxation of the erstwhile effective role of the States' Local Government Service Commission 
to call local governments to order and prevent them from drifting away from the path of financial sanity.

The problems of internal revenue generation in the Nigerian local government system according to Egonmwan (1984) are also compounded by the fact that the state governments have acquired the more lucrative, elastic and collectable revenue sources (e.g. water rates, motor vehicle license fees, form building plans), leaving local government with taxation with low ceilings, revenue which are administratively and politically difficult to exploit in an environment where the vast majority of the people are poor, self employed and dispersed in rural areas. The attitude of tax rate collectors in local governments also falls short of expectation. There were reported cases of fraud and embezzlement during our fact-finding visits to a number of councils, particularly in market stallage fees. Apart from the wrong attitudinal orientation of the collectors, collection of revenue, for example, from timber which would have constituted a viable source of revenue for local governments was hampered by illegal felling of trees, inefficiency of staff and other constraints. Their low level of training and the generally lazy attitude to work may also have accounted for poor collection of revenue. Inadequacy and inaccuracy of data were reported as the major setbacks in the collection of tenement rate - a source which is particularly lucrative in the urban areas. We also found during our fact finding visits to a number of Councils that rates and fees neither expanded with the growth of the economy nor with the rate of inflation. For example, some of the rates fixed in 1974 were still in force unrevised in many councils although the annual rates of inflation in 1974 was 12.6 percent in 1975, and dropping to 10.2 percent in 1980 with an annual growth rate at 18 percent in 1974 and 31 percent in 1979.

From the above discussion, we have seen the reasons generally given for poor internal revenue generation in most local governments in Nigeria. The discussion shows that the local governments are partly responsible for the problem. The reason is because most local governments do not tap to the full, existing internal revenue sources. They seem to be more interested in the collection of the statutory allocations from the centre. This explains why most local governments have not taken pains to revise the relevant by-laws that concern their internal revenue generation and collection to be in line with recent development or changes in the society.

Furthermore, most local governments in Nigeria today have become centres or fortresses of corruption. This problem was clearly highlighted in the Newswatch Magazine edition of December 20, 1993, captioned "Fortress of Corruption: Audit Report Indicts Local Government of Fraud and Corruption." In a seventy-four page audit report the following major issues were highlighted... all the Chairmen of the twenty-one local governments in a particular state were pronounced guilty of financial irresponsibility; that the local government councils had become fortresses of financial malpractices...

It is neither an exaggeration nor an overstatement if we say based on our experiences and available records, that the average revenue collector in the local government is corrupt. In fact, it is the corrupt practices of most revenue collectors that have denied the local governments opportunity to raise sufficient amounts of revenues from their different internal sources. It is the revenue collectors who in fact are largely responsible for the poor internal revenue generation; they collude with the members of the public, landlords, etc. to defraud and deny the local government of the revenue that should accrue to it. In most of our local governments today, corruption has taken different forms and dimensions, namely - endemic 
corruption, epidemic corruption, planned corruption, development corruption, among others. Therefore, corruption remained the most devastating single problem undermining efficient and effective internal revenue generation in Nigerian local governments today. We have, therefore, devoted sufficient space and efforts in suggestions in the subsequent section of this paper.

The problem of internal revenue generation in the Nigerian local governments can be summarized as observed by Onyishi (1995) to include: "poor revenue assessment and methods of collection; paucity of technically trained and experienced revenue assessors and collectors; obsolete revenue by-laws; sheer fraud, uncooperative and uncompromising attitude and ' 419 '/sharp practices on the part of tax, rate, rate and fees payers (that is, the relevant public); inefficient supervision and control, and ineffective auditing system." The problem of poor internal revenue generation is also compounded by the socio-political environment of the local government system in particular and the Nigerian society in general, which is predicated on prebendalism.

\section{Suggested Ways and Strategies for Maximizing Internal Revenue Generation in Local Governments in Nigeria}

As already mentioned above, if the existing legal sources of revenue are fully exploited and tapped, most local governments will need not to bother themselves seeking additional sources since the present sources provided by the existing laws will suffice. Therefore, in order to maximize its internal revenue generating capacity, a local government should think of the following action/ suggestions:

\section{a) Exploitation or Enforcement of the Existing Revenue Sources to the Full}

Local government in the country should Endeavour to exploit/tap to the full, existing sources of internal revenue generating capacities, especially in the following areas:

i) Community rates: Less than 30 percent of male taxable adults pay this tax at the local government level and machinery for its administration is inadequate and unsatisfactory. The traditional rulers or village heads should be made to assist in the collection of this rate since they know their subjects better.

ii) Property (Tenement) rates

iii) Licenses, Fees and Charges:

1) Advertisement fees

2) Brick making and block industry licenses

3) Contractors' registration fees

4) Forestry and fuel exploitation fees

5) Hawkers' permits/licenses in the markets

6) Liquor brewing/sales licenses

7) Control of noise licenses - for record and cassette sellers and loud speaker system - both in the markets and large ceremonial public gathering

8) Produce buying licenses

9) Rents and plot fees

10) Wholesale and retail trade licenses 
The existing laws on internal revenue yielding sources of local governments could be modified so as to improve their internal revenue yielding potentials in the following areas:

i) Taxes and Rates: Nigerians have recently become profligate spenders in merry-making and entertainment especially in the areas of marriages, funeral rites, title taking, birthday, house-warming, ceremonies, etc. Local governments should design local entertainment tax laws which will tap from and curtail the spending spree of Nigerians in those areas especially in these austere times.

ii) Rural Property (Tenement) Rates: Rural areas are not potential money yielding sources from commercial property rating. But many affluent Nigerians make their wealth in urban areas and come home to the rural areas to build mansions and palatial houses. Local governments should be able to exploit this tendency by designing appropriate property rates on rural residential house so that these wealthy Nigerians who evade taxation where they live in urban areas could be netted into the tax bracket by their rural local governments taxing their wealth through this improved source of tenement rating, known as rural property rates.

iii) Wholesale and Retail Trade Licenses: Experience has shown that Nigerians are very artful tax dodgers by nature. The result is that it is only public servants whose incomes are taxed from source under the PAYE system of taxation, who pay their taxes as and at when due. Wholesale and retail traders who make thousands of Naira every month in the rural markets only pay their community rates to the local governments. Local governments in Nigeria should as a matter of urgency design appropriate laws that tax both wholesale and retain traders in our rural markets.

iv) Produce Buying/Sale Licenses: Local government areas especially in Enugu, Anambra, Imo, Abia and Ebonyi States are noted for their palm oil/kernel and timber produce and sales, among others. Local governments could modify the existing licenses and fees on produce purchases and evacuation from their areas of authority.

\section{c) Development of New Areas of Revenue Yield}

Local governments in Nigeria could embark on investments that can yield them regular sources of revenue, apart from investing on stocks and shares in companies where they have little or no control. There new investment areas could be in the following areas:

- Mass Transit Transportation Programmes: Many local governments are already exploiting this potentially lucrative revenue source. This could be further improved and sometimes Federal Government help or assistance in this direction could be sought.

- Petrol Filling Stations: Local government could establish petrol filling stations in the rural areas to augment those of the private sector and this could improve the revenue base of local governments.

- Rural Pharmacy Houses and Medicine Stores: The Health Departments of our local governments should embark on this venture in the rural areas.

- Establishment of Poultry Farms/Fish Ponds: This could be established and commercially managed by the local government Department of Agriculture.

- Nursery Schools and Day-Care Centres: Local government could establish schools for children to pay fees, etc. 


\section{d) Minimization of Corruption and Administrative Waste}

No matter the amount of revenue generated internally in our local governments, no progress will be made in the society if the present level of official corruption, embezzlement of public funds, etc. by local government office holders (whether political, public or career officers) and the wider Nigerian community, continues. According to a recent report of a survey carried out by foreign private investor's worldwide, Nigeria ranks among the most corrupt country of the 70 countries included in the survey, while New Zealand is the least corrupt. This should be worrisome development to many right-thinking Nigerians and this goes to emphasize the fact that this country is due for a complete shakeup. So, unless corruption and waste in our local governments are minimized, the above suggestions for improving the internal revenue generation capacities of our local government will be unrealizable.

The first strategy in eliminating corruption and waste of funds and resources in the local government system is to develop adequate supervision and inspection technique to monitor revenue collection and ensure proper accountability. Adequate supervision and inspection technique will include among other things some of the following:

- Ascertainment of all sources of revenue accruable to the local government as defined by the law;

- Strict application of rules relating to the payment and collection of revenue from the different types or sources;

- Investigation of the procedures used by the revenue collectors in assessing the payers;

- Finally, investigation and appraisal of possible weakness - evasion, avoidance, administrative inefficiency and undermining that could affect the fiscal performance of the revenue collector.

\section{e) Use of Prevention and Detection Methods/Techniques}

Prevention and detection technique is a strategy for discovering internal revenue leakage, which simply means the loss of revenue by the local government through the connivance of the revenue collectors with the members of the revenue paying public. It also involves such activities as under-assessment of the revenue payers; illegal exemption of some revenue payers (e.g. friends, relations, wife, etc.) by the revenue collector; forging of receipts and non-remittance of revenue collected.

The prevention and detection techniques in internal revenue generation would entail the following:

- Serious bounding of revenue collectors and other revenue staff of the local government by well-known and wealthy Nigerians as a means of discouraging misappropriation;

- Revenue collectors and cashiers not being allowed to stay too long in one position to avoid perfection of strategy for misappropriation. In other words, constant change or reassignment of revenue collectors;

- Staff of proven integrity and transparent honesty be employed as revenue collectors and cashiers. Efforts should be made by the local government authority to ensure that dishonest staff or those with suspicious character are not recruited as revenue collector 
or cashier. Detailed investigation about the staff conduct, morals, life and background as well as previous records of service if any should be instituted.

\section{Regular Inspection and Auditing of the Revenue Records}

Government Inspector should regularly supervise and inspect the revenue books of the revenue collectors. Similarly, Internal Audit Unit of the local government must be strengthened and be up and doing in auditing the accounting records and revenue books of the revenue collectors and cashiers to ensure that no fund is diverted to private use. The Internal Audit Unit should be able to raise Audit Alarm when necessary.

\section{Avoid Posting Staff with Known or Chronic Financial Embarrassment Problems as Revenue Collectors and Cashiers}

As much as possible, efforts should be made to ensure that staff entrusted with the responsibility of revenue collections are those with sound financial discipline, standing and public respect. A staff that is well known to be always applying for loan, overdrafts or salary advance should not be deployed as a revenue collector because he will constitute a serious threat to the local government revenue.

\section{Adequate Salary and Remuneration for Revenue Staff}

The revenue collector and cashier should be adequately paid and rewarded to avoid the temptation of tampering with the revenue collected or colluding with the members of the public to defraud the local government of the much needed revenue. Adequate remuneration will encourage work motivation and satisfaction which will serve as a deterrent to dishonest or fraudulent practices.

\section{Conclusion}

We have seen from discussions above, that local governments have a lot of internal sources of revenue. These sources as can be seen have not been fully tapped or exploited by the local governments. It is interesting to note that local government themselves are largely responsible for non-maximization of their internal revenue sources. The reason for this is because they lack the political will to set the necessary machinery in motion for effective and efficient internal revenue generation.

The local governments pay more attention to collection of statutory allocations and lip service to internal revenue maximization. Most local governments have refused or paid little or no attention to updating their by-laws as they concern revenue payment, collection and enforcement. It is shocking and surprising to observe that some local governments still charge old rates and other fees as was the case during the colonial period. This they do notwithstanding the rate of inflation and other changes in the economy as well as the capacity and willingness of the members of the public to pay.

Apart from lack of political will by the local governments to maximize their internal revenue generation, there is also another problem on their part which is the prebendal attitude of their workers. Prebendalism is an attitude that public office is essentially held for personal gains. In other words, people seek for public office purely for personal gains. This attitude is 
manifest in most of the staff of the local governments, which today are "centres and fortresses" of corruption. However, this is a general cankerworm affecting the Nigerian society.

A number of measures have been suggested on how the local government can maximize their internal revenue generations. These measures have been fully discussed in the main body of the work. We strongly believe that if the above suggested measures are adopted by the local governments, they will revert back to self-sufficiency in internal revenue generation as was the case in pre-oil boom era in Nigeria.

\section{References}

Adewumi, J. B. (1994). Essential feature of the Revised Financial Memoranda for the local government. A commissioned background paper for National Orientation Workshop on the use of the Revised Financial Memoranda for senior local government functionaries organized by the Ministry of State and Local Government Affairs, Abuja from Sept. $22^{\text {nd }}-23^{\text {rd }}$ October, p. 1 .

Anambra State of Nigeria. Financial Memoranda issued under Section 93 of the Anambra State Local Government Edict No. 9 of 1976, pp. A21-A28.

Aniefiok, U., Chairman Uyo Local Government, Uyo, Akwa-Ibom State (1987). Improving local government revenue. Paper presented in a seminar to participants in the local government training programme, Sub-Department of Public Administration and Local Government, University of Nigeria, Nsukka. May, p. 5.

Egonmwan, J. A. (1984). Principles and Practice of Local Government in Nigeria. Benin City: S. M. O. Aka and Brothers Press.

Federal Government of Nigeria (1979). The Constitution of Federal Republic of Nigeria. Lagos: Federal Government Printer.

Newswatch Publication (1979). December 20, p. 25.

Onyishi, A. O. (1995). Accounting for revenue in the Nigerian local government system. A paper presented at the National Seminar/Workshop on Internal Revenue Generation: Strategies, problems and prospects. Awka: First Date Search Ltd.

The Report of the Committee on the fiscal and financial performance of local governments in the federation, $1978 / 79$, p. 2. 